\title{
Pemanfaatan Media Pembelajaran Online Di Saat Pandemi Covid-19
}

\author{
Muhammad Nur Ismail ${ }^{1}$, Rinto Alexandro ${ }^{1 *}$ \\ Program Studi Pendidikan Ekonomi, Fakultas Keguruan dan Ilmu Pendidikan, \\ Universitas Palangka Raya \\ *Email: rinto.alexandro@fkip.upr.ac.id
}

Diterima: 4 Februari 2021; Disetujui: 4 Maret 2021; Diterbitkan: 16 April 2021

\begin{abstract}
ABSTRAK
Negara Indonesia memiliki potensi bencana yang dapat mengganggu berbagai aspek kehidupan terutama dalam dunia pendidikan. Pada saat ini COVID-19 merupakan bencana yang sedang dihadapi mengharuskan semua komponen dalam dunia pendidikan secara cepat beradaptasi untuk melaksanakan pembelajaran. Tujuan penelitian ini adalah sebagai tinjauan umum terhadap pelaksanaan pembelajaran saat ini dimana pandemi COVID-19 tengah mewabah. Metode yang digunakan dalam penelitian ini adalah metode descriptive content analysis study. Metode ini dilakukan dengan menganalisis artikel dan sumber lain yang sejenis tentang media pembelajaran online pada masa pandemic COVID-19. Meskipun sekolah secara fisik ditutup untuk menghindari resiko penularan COVID-19 saat ini, untuk mengaktifkan kelas diperlukan media pembelajaran online agar pembelajaran tetap berjalan. Pembelajaran online merupakan solusi yang efektif, namun perlu dilakukan evaluasi terhadap teknik pembelajaran ini karena kemampuan untuk menyediakan fasilitas oleh pemerintah, sekolah maupun orang tua siswa sebarannya sangat berbeda di Indonesia.
\end{abstract}

Kata kunci: Media, Pembelajaran Online, COVID-19

\section{PENDAHULUAN}

Pandemi covid 19 telah memberikan dampak negatif yang belum pernah terjadi selama ini terhadap dunia pendidikan di Indonesia. Sistem pendidikan memiliki kekacauan yang tidak terukur dalam jangka pendek maupun jangka panjang. Kekacauan jangka pendek berupa pembelajaran yang dilakukan karena pembatasan social (social distancing) yang menyebabkan kegiatan belajar mengajar tidak dapat dilaksanakan secara tatap muka di sekolah.

Guru sebagai pendidik paling terdampak karena harus mengalami berbagai jenis kesulitan berupa mental, fisik, dan keuangan. Siswa juga mengalami berbagai macam kesulitan terutama pembelajaran daring yang memerlukan banyak biaya untuk pembelian perangkat elektronik dan pulsa untuk internet. Sedangkan kekacauan jangka panjang adalah kurikulum tidak dapat dilaksanakan dengan baik sehingga capaian kompetensi tidak dapat sepenuhnya tercapai.

Saat ini Indonesia tengah mengalami perubahan dasar dari pola hidup 
generasi usia sekolah yang disebut dengan kaum millennial. Generasi yang dilahirkan pada era dimana teknologi komunikasi dan informasi dapat dilihat hanya dengan genggaman tangan saja melalui perangkat smartphone. Informasi apa saja yang tidak terbatas kontennya dapat diketahui pada saat itu juga. Teknologi yang ada juga mendukung untuk berkomunikasi dengan siapapun pada saat itu juga, dimana saja, dan dengan siapa saja. Dunia pendidikan sebagai wadah dari generasi milenial tersebut untuk belajar perlu memperhatikan hal tersebut jangan sampai ketinggalan teknologi informasi dan komunikasi. Informasi dapat diperoleh dengan mudah dengan konten-konten yang menarik, sehingga jika sekolah tidak dapat memanfaatkan teknologi informasi dan komunikasi maka akan ditinggalkan oleh generasi usia sekolah.

Pembelajaran supaya dapat berhasil dengan baik diperlukan penggunaan media untuk mendukung interaksi dan komunikasi antara guru dan siswa menjadi efektif dalam pelaksanaan pembelajaran. Pembelajaran konvensional tidak diperlukan penggunaan media, atau menggunakan media yang sangat terbatas, tetapi untuk menghadapi era digital maka diperlukan media pembelajaran yang kompleks, menarik, dan tidak dibatasi oleh tempat dan waktu. Dengan demikian di saat ini ketika pandemic covid 19 dalam sedang melanda kita semua termasuk dunia pendidikan maka kita dipaksa untuk kreatif dalam menggunakan media pembelajaran yang tidak dibatasi oleh tempat dan waktu.

\section{Pembelajaran}

Belajar adalah upaya untuk menjadi lebih baik melalui pengalamanpengalaman seseorang. Pengalaman tersebut berasal dari diri sendiri maupun dari orang lain, baik itu berasal dari melihat, mendengar, merasakan, dan melihat. Idealnya belajar akan menghasikan output lebih baik pada seseorang yang berproses. Pembelajaran merupakan proses yang dilakukan oleh seseorang atau lembaga yang mengupayakan perubahan: pengetahuan, ketrampilan maupun sikap, yang relative permanen.

Pembelajaran diperlukan alat, metode dan teknik agar komunikasi dan penyampaian informasi dari guru ke siswa dapat tercapai secara efektif dan efisien. Komunikasi dapat berupa penyampaian informasi dari guru dan respon dari siswa menjadi mudah dimengerti dan dipahami tanpa penyampaian yang panjang dan berbelit -belit. Adanya inovasi dalam pemanfaatan media pembelajaran sesuai dengan kemajuan jaman dan perkembangan siswa akan dapat menunjang keberhasilan pembelajaran..

\section{Media pembelajaran}

Pada awalnya, pendidikan hanyalah penyampaian informasi pelajaran oleh seorang guru terhadap siswanya. Ilmu yang dimiliki oleh guru secara langsung disampaikan agar dapat diserap oleh siswa seketika itu juga. Perkembangan selanjutnya buku menjadi bahan untuk memperoleh pengetahuan yang dapat 
dipelajari di sekolah maupun di luar sekolah. Kombinasi guru dan buku berjalan sejak lama ketika kertas mulai dibuat secara masal di Negara ini. Kekurangan dari cara yang konvensional ini adalah siswa hanya memiliki pengetahuan yang terbatas dan sulit mengembangkan pikirannya. Pengetahuan ditransfer searah saja yaitu dari guru ke siswa dengan umpan balik yang minim sekali, bahkan hampir dipastikan pengetahuan siswa selalu menjadi bagian kecil dari pengetahuan guru mengenai hal yang diajarkan.

Sekarang ini dalam dunia pendidikan sudah dikenal adanya media pembelajaran yang digunakan sebagai alat bantu mengajar bagi para guru. Media digunakan untuk memudahkan peserta didik mampu memahami materi yang diajarkan oleh guru tersebut sehingga guru tidak hanya mengandalkan komunikasi langsung dan tidak langsung ataupun komunikasi verbal dan non verbal. Media Pembelajaran didefinisikan sebagai alat bantu berupa fisik maupun non fisik yang sengaja digunakan sebagai perantara antara guru dan siswa dalam memahami materi pembelajaran agar lebih efektif dan efisien. Sehingga materi pembelajaran lebih cepat diterima siswa dengan utuh serta menarik minat siswa untuk belajar lebih lanjut. Pendek kata, media merupakan alat bantu yang digunakan guru degan desain yang disesuaikan untuk meningkatkan kualitas pembelajaran (Musfiqon, 2012: 28).

Ruang lingkup media pembelajaran adalah meliputi segala alat, bahan, peraga, serta sarana dan prasarana di sekolah yang digunakan dalam proses pembelajaran. Media memberikan rangsangan pada siswa untuk belajar, memberikan pembelajaran semakin efektif dan efisien, bisa menyalurkan pesan secara sempurna, serta dapat mengatasi kebutuhan dan problem siswa dalam belajar. Lebih penting lagi media sengaja dipilih dalam proses pembelajaran. Sehingga media yang tidak berorientasi pada pencapaian tujuan pembelajaran bukan termasuk dalam ruang lingkup media pembelajaran.

Media pembelajaran menggunakan cara pengembangan mata pelajaran mealui eksplorasi bahan yang ada di lingkungan sekitar siswa akan membantu guru mengaitkan antara materi yang diajarkannya dengan situasi dunia nyata siswa dan mendorong siswa membuat hubungan antara pengetahuan yang dimilikinya dengan penerapannya dengan kehidupan mereka sebagai anggota keluarga dan masyarakat. Dalam kelas menggunakan media yang ada tugas guru adalah membantu siswa mencapai tujuan pembelajaran. Guru lebih banyak berurusan dengan strategi pembelajaran dari pada memberikan informasi dengan mengelola kelas sebagai sebuah tim yang bekerja bersama untuk menemukan pengetahuan dan keterampilan baru bagi siswa dengan menemukan sendiri, bukan dari guru.

Secara terminologi, menurut para ahli, media pembelajaran berarti sebagai berikut: Menurut Berlach dan Ely (1971) media pembelajaran cenderung diartikan alat-alat grafis, fotografis atau elektronis yang membantu dalam menangkap, memproses dan menyusun kembali informasi visual atau verbal. 
Menurut Heinich, dkk (1985), media pembelajaran adalah media-media yang membawa pesan-pesan atau informasi yang memiliki maksud pembelajaran. Menurut Martin dan Briggs (1986) media pembelajaran adalah keseluruhan sumber yang diperlukan untuk melakukan komunikasi dengan orang yang sedang belajar. Hal tersebut dapat berarti perangkat keras dan perangkat lunak yang digunakan pada perangkat keras yang digunakan untuk memahamkan peserta didik. Menurut Hamalik (1994), media pembelajaran adalah semua hal yang dapat digunakan untuk menyalurkan pesan (bahan pembelajaran), sehingga dapat merangsang perhatian, minat, pikiran dan perasaan orang yang sedang belajar dalam kegiatan belajar untuk mencapai tujuan pembelajaran tertentu.

Dari beberapa pengertian di atas, dapat disimpulkan bahwa media pembelajaran adalah segala sesuatu yang digunakan untuk menyampaikan pesan, dalam rangka merangsang pikiran, minat, perhatian, perasaan peserta didik sehingga mereka dapat memahami materi belajar yang diajarkan serta mendorong mereka untuk belajar. Tetapi secara lebih khusus, pengertian media dalam proses pembelajaran diartikan sebagai alat-alat grafis, fotografis, atau elektronis untuk menangkap, memproses, dan menyusun kembali informasi visual atau verbal. Dengan demikian media juga dapat diartikan sebagai segala sesuatu yang dapat dipergunakan untuk menyalurkan pesan, merangsang pikiran, perasaan, perhatian, dan kemauan siswa, sehingga dapat terdorong terlibat dalam proses pembelajaran. Media pembelajaran adalah segala sesuatu (manusia, pesan, alat atau kejadian) yang berisi materi pengajaran, berfungsi sebagai penyampai informasi kepada peserta didik dengan tujuan untuk merangsang siswa belajar

\section{Ciri-ciri media pembelajaran yang efektif}

Media pembelajaran seharusnya dapat membangkitkan rangsangan pada indera penglihatan, pendengaran, perabaan, penciuman, dan pengecapan pada siswa mengenai materi pelajaran yang disampaikan. Ciri-ciri umum media pembelajaran bisa dikatakan bahwa media itu dapat diraba, dilihat, didengar, dan diamati melalui panca indera yang dimiliki manusia. Selain itu media pembelajaran juga memiliki ciri-ciri sesuai dengan harganya, lingkup sasaranya, dan kontrol oleh pemakai.

Karakteristik yang perlu dipahami oleh pemakainya pada setiap media pembelajaran, sehingga dalam memilih media tersebut seorang guru perlu memperhatikan hal berikut ini, yaitu : 1) Pemilihan media sesuai dengan kejelasan maksud dan tujuan, 2) Memahami sifat dan ciri-ciri media yang akan digunakan, 3) pemilihan media dengan membandingkan beberapa media sehingga tujuan pembelajaran dapat tercapai dengan baik.

\section{Media pembelajaran di masa depan}

Pemanfaatan media daam pembelajaran, tidak dilakukan secara tiba-tiba, akan tetapi melalui beberapa proses tertentu yang dapat kita dipelajari dan 
dikembangkan untuk memahami media pembelajaran secara lebih utuh dan menyeluruh dan juga memiliki keharusan untuk memahami komunikasi multimedia seiring dengan perkembangan jaman. Dalam mengembangkan media pembelajaran dilakukan dengan mempelajari berbagai macam bentuk-bentuk komunikasi yang ada di sekitar kita sesuai dengan perkembangan peserta didik yang dinamis. Oleh karena itu dalam artikel ini akan disampaikan mengenai media pembelajaran yang selalu berkembang menjadi semakin modern.

1. Kerucut Pengalaman Edgar Dale

Bersamaan dengan munculnya AVA, Edgar Dale membuat sebelas klasifikasi tingkatan pengalaman belajar dari yang paling konkret sampai yang paling abstrak untuk membantu membuat alat bantu visual audio yang lebih membantu siswa dalam belajar. Klasifikasi Dale ini dikenal dengan nama "Kerucut Penglaman" (Cone of Experience). Pada masa ini, para pendidik sangat terpikat dengan kerucut pengalaman Dale sehingga pemilihan jenis media yang paling sesuai untuk memberikan pengalaman belajar tertentu pada siswa banyak dipengaruhi oleh teori Dale ini (bandingkan dengan teori sosial kognitif). Pada akhir tahun 1950, teori komunikasi mulai mempengaruhi penggunaan alat audio visual. Dalam pandangan teori komunikasi, alat audio visual berfungsi sebagai alat penyalur pesan.

Kerucut pengalaman ini, memiliki tingkatan-tingkatan sebagai berikut.

- Direct Purposeful Experiences, yaitu pengalaman yang diperoleh dari kontak langsung dengan lingkungan, objek, binatang, manusia, dan sebagainya, dan merupakan bentuk pembelajaran paling riil yang bisa dialami oleh siswa didik.

- Contrived Experiences, yaitu pengalaman yang diperoleh melalui interaksi dengan model, benda tiruan, atau simulasi dari realitas yang asli.

- Dramatized Experiences, yaitu pengalaman yang diperoleh melalui permainan, sandiwara boneka, permainan peran, drama sosial yang mencerminkan objek asli yang hendak dipelajari

- Demonstration, yaitu pengalaman yang diperoleh dari sebuah pertunjukan

- Study Trips, yaitu sebuah pengalaman yang diperoleh melalui karya wisata

- Exhibition, yaitu sebuah pengalaman yang diperoleh melalui pameran

- Educational Television, yaitu sebuah pengalaman yang diperoleh melalui televisi pendidikan

- Motion Pictures, yaitu pengalaman yang diperoleh melalui gambar, film hidup, bioskop tentang hal yang sedang dipelajari

- Still Pictures, yaitu pengalaman yang diperoleh melalui gambar mati, slide, fotografi yang mencerminkan realitas asli

- Radio and Recording, yaitu engalaman yang diperoleh melalui siaran radio atau rekaman suara atas suatu objek yang sedang dipelajari 
- Visual Symbol, yaitu pengalaman yang diperoleh melalui simbol yang dapat dilihat seperti grafik, bagan, atau diagram

- Verbal Symbol, yaitu pengalaman yang diperoleh melalui penuturan katakata dan merupakan pengalaman belajar yang paling rendah tingkat visualisasinya bagi siswa didik.

2. Computer Based Training (CBT)

- Kelebihan Computer Based Training (CBT)

- Tampilanya bisa menghasilkan kombinasi antara tulisan (teks), suara (audio), gambar (video), serta animasi.

- Dapat mengakses informasi secara instan dari manapun yang dicakup dari compact dist tersebut.

- Menghasilkan gambar yang lebih jelas.

- Program dan sistem computer based training (CBT) yang lebih canggih lebih memungkinkan pembelajaran mengakses lebih banyak, bukan hanya satu macam pilihan seperti pada audiotape atau videotape;

- Menyediakan fasilitas akses informasi yang lebih banyak.

- Dapat disesuaikan dengan motivasi, kemampuan dan kecepatan pembelajaran.

- Sebagai guru yang sabar

- Mengurangi kekhawatiran pembelajaran jika kurang paham.

- Kelemahan Computer Based Training (CBT)

- Kelemahan mendasar dari penggunaan program ini adalah tidak adanya iteraksi antarmanusia.

- Memerlukan biaya mahal.

3. Web Based Training (WBT)

- Kelebihan Web Based Training (WBT)

- Mengkombinasikan kelebihan video, kecepatan komputer, dan akses internet

- Mekanisme kerja program ini mampu menyesuaikan dengan semua gaya belajar

- Memungkinkan bagi pembelajar untuk aktif berpartisipasi.

- Memungkinkan akses ke materi/subyek yang diinginkan bagi banyak sekali pembelajar di tempat yang berbeda.

- Pembelajar dapat berhubungan dengan guru/instruktur, demikian sebaliknya dimanapun mereka berada.

- Kelemahan Web Based Training (WBT)

- Tidak terjadi temu muka antara guru/instruktur dengan pembelajar.

- Perlu biaya mahal untuk melengkapi peralatan. 
4. Internet

- Kelebihan Internet

- Memungkinkan akses informasi ke banyak nara sumber.

- Hampir semua tema dapat diperoleh dari Net.

- Bisa menjelajah dunia dari rumah, sekolah, kampus, kantor dan perusahaan.

- Adanya fasilitas untuk berinteraksi dengan orang lain dari seluruh penjuru dunia yang tertarik pada tema yang sama.

- Merupakan komunikasi dua arah, tanya jawab, mengobrol, membuat web sendiri, mengirim berita ke mana saja.

- Kelemahan Internet

- Biayanya mahal, karena untuk mengoperasikannya membutuhkan kelengkapan seperti komputer, modern ISP (Internet Service Provider), dan saluran telepon. Namun demikian kalau kita tidak memiliki perangkat tersebut kita bisa datang ke perpustakaan-perpustakaan atau ke tempat penyewaan internet;

- Diperlukan kemampuan mengoperasikan komputer, juga kemampuan memilih dari sejumlah pilihan yang semuanya kelihatan menarik bagi kita;

- Dibutuhkan ketelitian terhadap informasi yang ada, periksa kebenarannya, sebab tidak semua informasi selalu benar atau baik untuk kita.

\section{METODE PENELITIAN}

Penelitian ini menggunakan metode descriptive content analysis study. Metode ini merupakan analisis isi yang dimaksudkan untuk menggambarkan isi dari suatu informasi atau teks tertentu (Munirah, 2015). Analisis dilakukan pada berbagai artikel ilmiah terkait media pembelajaran selama masa pandemic COVID-19 dan media pembelajaran masa depan. Artikel ilmiah diperoleh dari jurnal internasional, nasional dan berbagai sumber lain yang sejenis.

\section{HASIL PENELITIAN DAN PEMBAHASAN}

Penyebaran Corona Virus Disease 2019 (COVID-19) yang menyebar di seluruh dunia termasuk di Indonesia saat ini dihadapi oleh Pemerintah melalui kebijakan social distancing maupun physical distancing guna meminimalisir penyebaran dan dampak yang akan diakibatkan. Kebijakan tersebut disikapi oleh dunia pendidikan melalui penutupan sekolah, meskipun demikian kelas dan pembelajaran tetap aktif meskipun dalam keterbatasan. Pembelajaran jarak jauh atau pembelajaran di rumah dengan memanfaatkan berbagai media penunjang pembelajaran yang mendukung adalah pilihan agar proses pendidikan tetap berjalan.

Selama kebijakan social distancing maupun physical distancing dimasa 
pandemi COVID-19 masih merajalela maka perlu dilakukan pemanfaatan media pembelajaran untuk menunjang pembelajaran jarak jauh agar guru dan siswa tetap dapat melakukan pembelajaran meskipun di rumah. Ketika sekolah-sekolah merespon COVID-19, kebutuhan akan media pembelajaran jarak jauh sangat mendesak untuk mempermudah transisi ke pembelajaran jarak jauh. Berbagai sumber daya dan teknologi komunikasi pendukung pembelajaran jarak jauh sebagai transfer pengalaman dapat dilaksanakan melalui video, audio, gambar, komunikasi teks, dan perangkat lunak. Hubungan guru dan siswa melalui sumber daya dan teknologi tersebut dapat menyatukan percakapan, konten, dan aplikasi disatu tempat, sehingga memungkinkan guru untuk melakukan pembelajaran dengan menciptakan lingkungan pembelajaran yang penuh semangat.

Media pembelajaran untuk mendukung pembelajaran jarak jauh dapat berupa Microsoft 365, Google Classroom, Whatsapp, dan lain sebagainya. Fitur dan software tersebut dapat digunakan sebagai media pembelajaran dengan mengirimkan teks, gambar, video, dan file dalam berbagai format kepada siswa yang sedang belajar di lain tempat. Pembelajaran dapat dilaksanakan secara face to face dengan lokasi yang berbeda dan mungkin juga dlam waktu yang berbeda pula, meskipun demikian guru dan siswa dapat berinteraksi secara virtual dengan fasilitas pesan instan dan kegiatan presentasi (Wiranda \& Adri, 2019). Media pembelajaran memberikan pengalaman manusia yang diperoleh dari kontak langsung dengan lingkungan, objek, binatang, manusia, dan sebagainya, dan merupakan bentuk pembelajaran paling riil yang bisa dialami oleh siswa didik, sedangkan pengalaman manusia yang diperoleh hanya melalui penuturan katakata merupakan pengalaman belajar yang paling rendah tingkat visualisasinya bagi siswa didik.

Variasi platform dan seumber daya yang tersedia membantu menunjang proses

pembelajaran selama pandemic COVID-19. Aktifitas pembelajaran yang dapat dilakukan mulai dari diskusi, presentasi hingga pemberian tugas. Ini selaras dengan penelitian Firman dan Rahayu (2020) bahwa pembelajaran online melatih kemandirian belajar. Ini akan membutuhkan keterlibatan peserta didik yang lebih besar untuk meningkatkan perilaku belajar observasional. Perilaku tersebut dapat dilakukan dengan membaca, memaknai postingan diskusi dan mendiskusikan video atau konten pembelajaran (Zayapragassarazan, 2020). Ini akan membiasakan peserta didik untuk mengumpulkan dan mengelola informasi terkait tugas yang diberikan tanpa batasan ruang dan waktu. Hal ini dikarenakan pembelajaran online memungkinkan akses informasi dan pengetahuan dirumah dan dimanapun yang disesuaikan dengan kenyamanan peserta didik.

Belajar online menuntut peran pendidik mengevaluasi efektivitas dan disesuaikan dengan kebutuhan belajar. Ini penting dilakukan untuk tetap memenuhi aspek pembelajaran seperti proses pengetahuan, moral, keterampilan, kecerdasan dan estetika. Mengingat bahwa perubahan ke pembelajaran online 
secara tidak langsung berpengaruh pada daya serap peserta didik (Dewi, 2020). Penting untuk diperhatikan yakni komunikasi orang tua dan pendidik untuk mewujudkan kemandirian belajar peserta didik selama masa pandemic COVID19.

Pembelajaran online menjadi solusi efektif untuk mengaktifkan kelas meski sekolah telah ditutup mengingat waktu dan tempat menjadi beresiko pada masa pandemic ini. Namun, teknik pembelajaran ini penting untuk dievaluasi sesuai dengan kondisi setempat mengingat sebaran fasilitas dan kemampuan orang tua memberikan fasilitas pembelajaran online berbeda kepada peserta didik di Indonesia (Herliandry et al., 2020).

Ragam manfaat yang diperoleh, tentu memiliki kendala yang dirasakan pendidik maupun peserta didik dalam pembelajaran online. Kendala yang dihadapi yakni kondisi wilayah di Indonesia yang beragam menyebabkan tidak semua wilayah terjangkau oleh layanan internet dan sebaran jaringan internet yang lamban sewaktu-waktu (Khasanah et al., 2020). Ini juga memungkinkan penggunaan internet yang tinggi berpengaruh pada kesehatan peserta didik. Kendala lain yang ditemukan yakni kemampuan orang tua untuk memberikan fasilitas pendidikan online (Obiakor \& Adeniran, 2020) seperti penggunaan jaringan internet yang membutuhkan biaya (Jones \& Sharma, 2019; Purwanto et al., 2020).

Permasalahan tersebut tentu harus tetap di evaluasi guna memperoleh pembelajaran yang lebih baik. Kuncinya adalah untuk melakukan pembelajaran online sesaui dengan kondisi setempat. Hal terpenting untuk menciptakan kemandirian dan keterampilan belajar peserta didik di tengah pandemic COVID19.

\section{KESIMPULAN}

Proses belajar mengajar dapat berlangsung dengan beradaptasi sesuai situasi dan kondisi yang ada. Negara Indonesia memiliki banyak sekali potensi gangguan terhadap pelaksanaan pembelajaran di sekolah, salah satunya adalah pandemic COVID-19 yang saat ini dihadapi bersama. Perkembangan teknologi memberikan solusi untuk menunjang terlaksananya pembelajaran yaitu melalui media pembelajaran online. Media tersebut memberikan kemudahan dalam proses pembelajaran untuk berkomunikasi dan transfer informasi. Banyak manfaat yang diberikan dari kemudahan pembelajaran online yang disediakan oleh berbagai platform melalui tatap muka dan diskusi secara virtual dapat dilaksanakan. Dengan demikian pemanfaatan media pembelajaran online harus selalu dikembangkan dan didukung dengan sarana dan prasarana yang memadai. 
Saran

Pemanfaatan media pembelajaran online perlu dilakukan evaluasi dan disesuaikan dengan kondisi setempat. Orang tua siswa memiki kemampuan yang berbeda dalam memberikan fasilitas pembelajaran online sesuai dengan kondisi ekonomi. Yang terpenting adalah memaksimalkan kemampuan seluruh komponen pendidikan, terutama guru dan siswa untuk belajar dalam kondisi pandemik seperti sekarang ini.

\section{DAFTAR PUSTAKA}

Abidah, A., Hidaayatullaah, H. N., Simamora, R.M., Fehabutar, D., \& Mutakinati, L. (2020). The Impact of Covid-19 to Indonesian Education and Its Relation to the Philosophy of "Merdeka Belajar." Studies in Philosophy of Science and Education, 1(1), 38-49. https://doi.org/10.15408/sjsbs.v7i3.15104

Ahmed, S., Shehata, M., \& Hassanien, M. (2020). Emerging Faculty Needs for Enhancing Student Engagement on a Virtual Platform. MedEdPublish, 15. https://doi.org/10.15694/mep.2020.000075.1

Banggur, M. D. V., Situmorang, R., \& Rusmono. (2018). Pengembangan Pembelajaran Berbasis Blended Learning pada Mata Pelajaran Etimologi Multimedia. JTP -Jurnal Teknologi Pendidikan, 20(2), 152-165. https://doi.org/10.21009/JTP2002.5

Dewi, W. A. F. (2020). Dampak Covid-19 Terhadap Implementasi Pembelajaran Daring Di Sekolah. 2(1), 55-61.

Firman, \& Rahayu, S. (2020). Pembelajaran Online di Tengah Pandemi Covid-19. Indonesian Journal of Educational Science (IJES), 2(2), 81-89.

https://doi.org/10.31605/ijes.v2i2.659

Gugus Tugas Percepatan Penanganan COVID-19 Indonesia. (2020). Data COVID-19 Global dan Indonesia. https://covid19.go.id/

Herliandry, L. D., Nurhasanah, Suban, M. E., Kuswanto, H.(2020). Pembelajaran Pada Masa Pandemi Covid-19. Jurnal Teknologi Pendidikan, 22 (1), 6570. https://doi.org/10.21009/jtp.v22i1.15286

Riyana, C., (2012). Media Pembelajaran. Jakarta. Kementrian Agama RI.

Wiranda, T., \& Adri, M. (2019). Rancang Bangun Aplikasi Modul Pembelajaran Teknologi WAN Berbasis Android. VoteTEKNIKA(Vocational Teknik Elektronika Dan Informatika), 7(4), 2302-3295. http://ejournal.unp.ac.id/index.php/voteknika/index 